\title{
Protein quality of insects as potential ingredients for dog and cat foods*
}

\author{
Guido Bosch ${ }^{1 \dagger}$, Sheng Zhang ${ }^{1}$, Dennis G. A. B. Oonincx ${ }^{2}$ and Wouter H. Hendriks ${ }^{1}$ \\ ${ }^{1}$ Animal Nutrition Group, Wageningen University, PO Box 338, 6700 AH Wageningen, The Netherlands \\ ${ }^{2}$ Laboratory of Entomology, Wageningen University, PO Box 8031, $6700 \mathrm{EH}$ Wageningen, The Netherlands
}

(Received 7 November 2013 - Final revision received 26 January 2014 - Accepted 20 February 2014)

Journal of Nutritional Science (2014), vol. 3, e29, page 1 of 4

doi:10.1017/jns.2014.23

Abstract

Insects have been proposed as a high-quality, efficient and sustainable dietary protein source. The present study evaluated the protein quality of a selection of insect species. Insect substrates were housefly pupae, adult house cricket, yellow mealworm larvae, lesser mealworm larvae, Morio worm larvae, black soldier fly larvae and pupae, six spot roach, death's head cockroach and Argentinean cockroach. Reference substrates were poultry meat meal, fish meal and soyabean meal. Substrates were analysed for DM, N, crude fat, ash and amino acid (AA) contents and for in vitro digestibility of organic matter (OM) and $\mathrm{N}$. The nutrient composition, AA scores as well as in vitro $\mathrm{OM}$ and $\mathrm{N}$ digestibility varied considerably between insect substrates. For the AA score, the first limiting AA for most substrates was the combined requirement for Met and Cys. The pupae of the housefly and black soldier fly were high in protein and had high AA scores but were less digestible than other insect substrates. The protein content and AA score of house crickets were high and similar to that of fish meal; however, in vitro $\mathrm{N}$ digestibility was higher. The cockroaches were relatively high in protein but the indispensable AA contents, AA scores and the in vitro digestibility values were relatively low. In addition to the indices of protein quality, other aspects such as efficiency of conversion of organic side streams, feasibility of mass-production, product safety and pet owner perception are important for future dog and cat food application of insects as alternative protein source.

Key words: Dog: Cats: Nutritional value: Amino acid composition: In vitro digestibility

Trends towards 2050 predict an increased demand for animalderived protein sources for human foods due to the combined effects of human population increase and increasing standards of living in developing countries ${ }^{(1)}$. This demand will increase the global competition for proteins in human food, pet food and livestock feed and stimulate the development of alternative and sustainable protein sources for assuring food security. The Food and Agricultural Organization of the United Nations has highlighted the potential of insects as food and feed sources ${ }^{(2)}$. Insects are in general proteinaceous ${ }^{(3)}$ and some species can be efficiently grown on organic side streams making these potentially sustainable alternatives for current proteinaceous feed ingredients ${ }^{(3-5)}$. In addition, insects are commonly consumed by feral cats around the world contributing up to $6 \%$ of their diet ${ }^{(6)}$. The information on the protein quality is, however, currently limited for most insect species. The aim of the present study was, therefore, to evaluate the protein quality of a selection of insect species as potential ingredients for $\operatorname{dog}$ and cat foods.

\section{Experimental methods}

\section{Substrates}

Insect substrates were housefly pupae (Musca domestica) (donated by Jagran B. V. Hillegom), adult house cricket (Acheta domesticus), yellow mealworm larvae (Tenebrio molitor), lesser mealworm larvae (Alphitobius diaperinus), Morio worm larvae (Zophobas morio) (all purchased from Kreca), black

Abbreviations: AA, amino acid; CP, crude protein; OM, organic matter.

†Corresponding author: G. Bosch, email guido.bosch@wur.nl

* This article was published as part of the WALTHAM International Nutritional Sciences Symposium Proceedings 2013. 
soldier fly (Hermetia illucens) larvae and pupae (donated by Laboratory of Entomology, Wageningen University) and adult six spot roach (Eublaberus distanti), adult death's head cockroach (Blaberus craniifer) and adult female Argentinean cockroach (Blaptica dubia) (donated by D. G. A. B. Oonincx). The black soldier fly larvae were fed a broiler starter diet (Agruniek Rijnvallei Voer BV) and the roaches were fed household food waste. The other insect species were sourced from companies that keep the diet compositions confidential. Reference substrates were poultry meat meal (Sonac), fish meal (Research Diet Services) and soyabean meal (Research Diet Services). Housefly pupae, black soldier fly larvae, and pupae and cockroaches were freeze-dried to a constant weight. House crickets, yellow mealworms, lesser mealworms and Morio worms were already freeze-dried. Remaining poultry manure attached to the housefly pupae and dirt attached to black soldier fly pupae were removed by hand. Before milling, housefly pupae, Morio worms, black soldier fly larvae and pupae, and cockroaches were broken using an ultracentrifugal mill without a sieve (Retsch ZM 100, F. Kurt Retsch GmbH\& Co. KG). Then these insects were ground using a laboratory analytical mill (A10, Janke \& Kunkel GmbH u. Co KG), except for house crickets that were ground in centrifugal mill with a $1 \mathrm{~mm}$ sieve (Retsch ZM 100). Reference substrates were already in a dried and ground form.

\section{In vitro digestion}

Substrates were in vitro digested according to an up-scaled Boisen two-step method $^{(7)}$ with modifications ${ }^{(8,9)}$ simulating the canine gastric and small intestinal digestive processes. Chloramphenicol was added during incubation for its antibiotic effect. The number of replicate incubations required was calculated on the anticipated amount of residue per replicate and the total amount of residue required for chemical analyses. Substrates $(10 \mathrm{~g})$ were incubated in beakers with a phosphate buffer solution $(250 \mathrm{ml}, 0 \cdot 1 \mathrm{M}, \mathrm{pH} 6 \cdot 0)$ and an $\mathrm{HCl}$ solution $(100 \mathrm{ml}, 0 \cdot 2 \mathrm{M})$. The $\mathrm{pH}$ was adjusted to $2 \cdot 0$ with $1 \mathrm{M} \mathrm{HCl}$ or $10 \mathrm{~m} \mathrm{NaOH}$. Fresh pepsin solution $(10 \mathrm{ml}, 25 \mathrm{~g} / \mathrm{l}$, porcine pepsin $2000 \mathrm{FIP} \mathrm{U} / \mathrm{g}$, Merck 7190) and $10 \mathrm{ml}$ chloramphenicol solution $(0.005 \mathrm{~g} / \mathrm{mol}$ ethanol) were added and each beaker was covered with a glaze and placed in a heating chamber at $39^{\circ} \mathrm{C}$ for $2 \mathrm{~h}$ under constant magnetic stirring. Then, $90 \mathrm{ml}$ phosphate buffer $(0.2 \mathrm{M}, \mathrm{pH} 6.8)$ and $50 \mathrm{ml}$ of a $0.6 \mathrm{~m} \mathrm{NaOH}$ were added into the solution. The $\mathrm{pH}$ was adjusted to 6.8 with $1 \mathrm{M} \mathrm{HCl}$ or $10 \mathrm{~m} \mathrm{NaOH}$. Fresh pancreatin solution $(10 \mathrm{ml}$, $100 \mathrm{~g} / 1$ pancreatin, Porcine pancreas grade VI, SigmaP-1750) was added and incubation was continued for $4 \mathrm{~h}$ under the same conditions. After incubation, the residues were collected by filtration of the slurries on a nylon gauze $(37 \mu \mathrm{m})$ folded in a Büchner porcelain funnel. The sample was washed twice with acetone $(99.5 \%)$ followed by ethanol (96\%). Then the cloth with the residue was temporarily placed on a clean paper to evaporate the remaining ethanol/acetone overnight. The residue was collected from the nylon cloth and dried at $70^{\circ} \mathrm{C}$ overnight in a preweighed jar. Then the oven-dried jars were reweighed to determine the amount of dry residue for each replicate, which allowed the calculation of DM digestibility for each replicate. For each type of substrate, the selected oven-dried residues were pooled and ground in laboratory analytical mill (A10, Ika-Werk). The ground residues were transferred into a new jar, pending further chemical analyses for calculating the in vitro DM, organic matter (OM) and $\mathrm{N}$ digestibility for each substrate.

\section{Chemical analyses}

$\mathrm{DM}$ and ash were determined by drying to a constant weight at $103^{\circ} \mathrm{C}$ and combusting at $550^{\circ} \mathrm{C}$, respectively. Nitrogen was determined using the Kjeldahl $\operatorname{method}^{(10)}$, and crude fat was analysed according to the Berntrop method ${ }^{(11)}$. Amino acids (AA) were analysed by ion exchange chromatography and ninhydrin derivatisation ${ }^{(12)}$.

\section{Calculations}

OM content was calculated at the 100 - ash content (percentage of DM). Crude protein (CP) was calculated as $6 \cdot 25 \times \mathrm{N}$ and AA content was expressed as percentage of $\mathrm{CP}$. Digestibility of substrate $\mathrm{OM}$ and $\mathrm{N}$ was calculated as the amount of residue collected (in $\mathrm{g} \mathrm{DM}) \times$ content in residue (in percentage of DM basis)/amount of substrate incubated (in $\mathrm{g} \mathrm{DM}$ ) $\times$ content in substrate (in percentage of $\mathrm{DM}$ basis). The AA scores were calculated as described in Kerr et $a l^{(13)}$ using minimal requirements for growth of kittens and puppies ${ }^{(14)}$ as reference values.

\section{Results and discussion}

Protein and fat contents varied considerably between insect substrates (Table 1). The CP content of insect substrates was in general higher than that in soyabean meal and close to that in poultry meat meal and fish meal. House crickets contained the most CP followed by lesser mealworms and the roaches. Fat content ranged from 12.8 to $39.6 \%$ of DM for black soldier fly larvae and Morio worms, respectively. Crude ash content of insect substrates was between 3.0 and $5.6 \%$ of DM, except for the black soldier fly larvae and pupae containing about $13 \%$. Ash contents of black soldier fly larvae ranged in literature from 9.0 to $14.6 \%$ of $\mathrm{DM}^{(15,16)}$ and $15.5 \%$ of DM in prepupae ${ }^{(17)}$. Phe and Met contents of CP varied the most between insect substrates, with highest contents found for the housefly pupae. Housefly pupae were also high in Lys as were the lesser mealworms. House crickets were relatively high in Arg but low in His. As it has been suggested that $\mathrm{CP}$ approximates the true protein for most species of insects $^{(18)}$, the AA were expressed on a CP basis to gain insight in the protein quality. Chitin contributes to non-protein $\mathrm{N}$ and contributes $1-7 \%$ of the whole-body $\mathrm{N}^{(18)}$. Differences in chitin content of insect substrates may confound the estimation of protein quality. AA contents for insect species vary considerably among studies. For example, for house crickets, Arg content in the present study $(5.7 \%$ of $\mathrm{CP})$ was within the range of other studies ${ }^{(3)}(4.9-6.0 \%$ of CP) but His was higher (3.4 v. $2 \cdot 1-2 \cdot 6 \%$ of CP). Depending on the diet fed, Met content of yellow mealworms ranged from 0.48 to $1.80 \%$ of 
Table 1. Proximate composition (percentage of DM), indispensable amino acid composition (percentage of CP) and amino acid (AA) score of insect and reference substrates

\begin{tabular}{|c|c|c|c|c|c|c|c|c|c|c|c|c|c|}
\hline \multirow[b]{2}{*}{ Parameter } & \multicolumn{10}{|c|}{ Insect substrates } & \multicolumn{3}{|c|}{ Reference substrates } \\
\hline & $\mathrm{HFp}$ & BSFI & BSFp & $\mathrm{HC}$ & YMW & LMW & MW & SSR & DHCR & $\mathrm{ACR}^{*}$ & PMM & FM & SBM \\
\hline $\mathrm{CP}$ & 62.5 & $56 \cdot 1$ & $52 \cdot 1$ & $70 \cdot 6$ & 52.0 & $64 \cdot 8$ & $47 \cdot 0$ & $66 \cdot 3$ & $65 \cdot 0$ & 64.4 & 69.1 & 71.0 & 51.6 \\
\hline Fat & $19 \cdot 2$ & $12 \cdot 8$ & $19 \cdot 7$ & $17 \cdot 7$ & 33.9 & $22 \cdot 2$ & 39.6 & $25 \cdot 1$ & $22 \cdot 0$ & 24.5 & $12 \cdot 8$ & $9 \cdot 2$ & 2.5 \\
\hline $\begin{array}{l}\text { Ash } \\
A A\end{array}$ & $5 \cdot 6$ & $12 \cdot 6$ & 13.9 & $5 \cdot 3$ & $3 \cdot 9$ & $4 \cdot 1$ & $3 \cdot 0$ & $3 \cdot 6$ & 3.9 & 4.4 & $15 \cdot 4$ & $19 \cdot 9$ & $6 \cdot 8$ \\
\hline Arg & 4.2 & 3.7 & 4.2 & 5.7 & 4.6 & 4.8 & 4.6 & 3.6 & 3.9 & 3.5 & 5.8 & 4.5 & 6.3 \\
\hline His & $4 \cdot 8$ & 4.4 & 4.7 & 3.4 & $5 \cdot 1$ & 4.9 & 4.8 & $4 \cdot 3$ & 4.6 & 4.5 & 3.7 & 3.4 & 3.1 \\
\hline Ile & $4 \cdot 0$ & 4.0 & $4 \cdot 2$ & 4.0 & 4.6 & 4.6 & $5 \cdot 0$ & 3.4 & $3 \cdot 7$ & $3 \cdot 2$ & 3.8 & 4.8 & 5.0 \\
\hline Leu & $6 \cdot 1$ & $6 \cdot 1$ & 6.5 & $6 \cdot 6$ & 7.3 & $6 \cdot 7$ & $7 \cdot 2$ & 5.4 & 5.9 & $5 \cdot 3$ & $6 \cdot 4$ & 7.1 & 7.8 \\
\hline Lys & 6.2 & 5.4 & 5.4 & 5.8 & 5.5 & 6.5 & 5.3 & 4.3 & 4.7 & 4.0 & 5.6 & 7.4 & 6.2 \\
\hline Met & 2.6 & 1.4 & 1.7 & 1.6 & 1.4 & 1.3 & 1.6 & 1.3 & 1.2 & 1.3 & 1.0 & 1.9 & 2.0 \\
\hline Phe & $5 \cdot 2$ & $3 \cdot 1$ & $3 \cdot 3$ & $3 \cdot 2$ & 3.4 & 3.9 & 3.7 & 2.6 & $2 \cdot 7$ & $2 \cdot 7$ & 3.3 & 3.5 & $5 \cdot 2$ \\
\hline Thr & 3.8 & $3 \cdot 6$ & 3.6 & 3.6 & 4.0 & 4.0 & $4 \cdot 1$ & 3.1 & $3 \cdot 3$ & 3.1 & 3.6 & 4.0 & 3.9 \\
\hline Val & 5.0 & 5.5 & 5.7 & 5.7 & $6 \cdot 3$ & 5.9 & 6.5 & 5.6 & $6 \cdot 1$ & 5.4 & 4.6 & 5.0 & 5.0 \\
\hline $\begin{array}{l}\text { tlAA } \\
A A \text { scorest }\end{array}$ & $41 \cdot 8$ & $37 \cdot 1$ & $39 \cdot 3$ & $39 \cdot 6$ & $42 \cdot 3$ & $42 \cdot 7$ & $42 \cdot 7$ & 33.5 & $36 \cdot 2$ & 33.1 & $37 \cdot 8$ & 41.5 & 44.4 \\
\hline Dog & 94.0 & 63.4 & 74.4 & $69 \cdot 3$ & 68.4 & $60 \cdot 4$ & 73.8 & 53.0 & 55.5 & 59.7 & 44.6 & 73.1 & 89.1 \\
\hline Cat & $106 \cdot 1$ & 79.2 & 93.0 & 86.6 & 85.5 & 75.5 & 92.2 & $66 \cdot 2$ & 69.4 & 74.6 & 55.8 & 91.6 & 107.5 \\
\hline
\end{tabular}

$\mathrm{CP}$, crude protein; HFp, housefly pupae; BSFI and BSFp, black soldier fly larvae and pupae; HC, house cricket; YMW, yellow mealworm; LMW, lesser mealworm; MW, Morio worm; SSR, six spot roach; DHC, death's head cockroach; ACR, Argentinean cockroach; PMM, poultry meat meal; FM, fish meal; SBM, soyabean meal; tIAA, total indispensable amino acids.

*Females.

†Calculated as described in Kerr et al..$^{(13)}$ using minimal requirements for growth of kittens and puppies ${ }^{(14)}$ as reference values.

$\mathrm{CP}^{(19)}$. For application of insects as a protein source in pet food or feed, it would be of importance to monitor and control the variation in AA composition. Met and Cys in poultry meat meal was lower in the present study than reported in the literature, i.e. $1.05 v .1 .07 \%$ in Clapper et al. ${ }^{(20)}$ to $2.11 \%$ in Johnson et al. ${ }^{(21)}$ and $0.69 \%$ (data not shown) $v .1 .34 \%$ in Clapper et al. ${ }^{(20)}$ to $2.66 \%$ in Murray et al. ${ }^{(22)}$, respectively. For the AA score, the first limiting AA for most substrates was the combined requirement for Met and Cys. Highest AA scores were found for housefly pupae, followed by black soldier fly pupae and Morio worm and lowest scores for the cockroaches.

In vitro $\mathrm{OM}$ digestibility was highest for yellow mealworms, Morio worms and lesser mealworms (Table 2). Black soldier fly pupae had lowest in vitro OM digestibility and was $16.2 \%$ lower than for the larvae. This difference in digestibility is likely caused by a higher cuticular protein-sclerotisation in the pupae. In vitro $\mathrm{N}$ digestibility was relatively high for the house crickets, yellow mealworms, lesser mealworms and Morio worms and low for black soldier fly pupae, six spot roach and death's head cockroach. Information on the digestibility of evaluated insect species is limited in the literature. Apparent faecal $\mathrm{N}$ digestibility of a diet containing 33\% black soldier fly larvae meal as the main protein source was $76.0 \%$ in $8.2-14.7 \mathrm{~kg}$ barrows ${ }^{(16)}$ and a diet containing 50 $\%$ housefly pupae meal had an apparent faecal $\mathrm{N}$ digestibility of $79.0 \%$ in broilers ${ }^{(23)}$.

Selected insect substrates differed considerably in nutrient composition as well as in vitro $\mathrm{OM}$ and $\mathrm{N}$ digestibility. Of the insect substrates studied, the pupae of the housefly and black soldier fly were high in CP and had high AA scores but were less digestible than the other insect substrates. The $\mathrm{CP}$ content and AA score of house crickets were high and similar to that of fish meal but with slightly higher in vitro
Table 2. In vitro digestibility (\%) of insect and reference substrates

\begin{tabular}{lll}
\hline & \multicolumn{2}{c}{ Digestibility } \\
\cline { 2 - 3 } \multicolumn{1}{c}{ Substrate } & OM & $\mathrm{N}$ \\
\hline Insect & & \\
Housefly pupae & 83.2 & 84.3 \\
BSF larvae & 84.3 & 89.7 \\
BSF pupae & 68.1 & 77.7 \\
House cricket & 88.0 & 91.7 \\
Yellow mealworm & 91.5 & 91.3 \\
Lesser mealworm & 90.2 & 91.5 \\
Morio worm & 91.1 & 92.0 \\
Six spot roach & 77.8 & 76.4 \\
Death's head CR & 79.4 & 78.4 \\
Argentinean CR & 84.0 & 83.8 \\
Reference & & \\
Poultry meat meal & 85.8 & 87.9 \\
Fish meal & 82.1 & 85.7 \\
Soyabean meal & 80.6 & 94.7 \\
\hline
\end{tabular}

OM, organic matter; BSF, black soldier fly; CR, cockroach. ${ }^{\star}$ Females.

$\mathrm{N}$ digestibility. The cockroaches were relatively high in $\mathrm{CP}$ but the indispensable AA contents, the AA scores and in vitro digestibility values were relatively low. Next to these indices of protein quality, other aspects such as efficiency of conversion of organic side streams ${ }^{(2,24)}$, feasibility of mass-production ${ }^{(24)}$, product safety ${ }^{(24,25)}$ and pet owner perception will determine if insect species are used in future pet food formulations. These and other aspects require further study.

\section{Acknowledgements}

This research was funded by Wageningen University. All authors contributed fundamentally to the present manuscript. G. B. contributed to all facets including research questions and design, 
execution of the study, analysing the data and writing the initial manuscript. S. Z. contributed to execution of the study, analysing the data and writing the manuscript. D. G. A. B. O. contributed to research design, data interpretation and manuscript preparation. W. H. H. contributed to securing funding, data interpretation and manuscript preparation. There are no conflicts of interest to declare.

This paper was published as part of the WALTHAM International Nutritional Sciences Symposium Proceedings 2013, publication of which was supported by an unrestricted educational grant from Mars Incorporated. The papers included in these proceedings were invited by the Guest Editor and have undergone the standard journal formal review process. They may be cited.

\section{References}

1. Boland MJ, Rae AN, Vereijken JM, et al. (2013) The future supply of animal-derived protein for human consumption. Trends Food Sci Technol 29, 62-73.

2. Van Huis A, Van Itterbeeck J, Klunder H, et al. (2013) Edible Insects: Future Prospects for Food and Feed Security. Rome: Food and Agriculture Organization of the United Nations (FAO).

3. Rumpold BA \& Schlüter OK (2013) Nutritional composition and safety aspects of edible insects. Mol Nutr Food Res 57, 802-823.

4. Van Huis A (2013) Potential of insects as food and feed in assuring food security. Annu Rev Entomol 58, 563-583.

5. Veldkamp T, van Duinkerken G, van Huis A, et al. (2012) Insects as a Sustainable Feed Ingredient in Pig and Poultry Diets: a Feasibility Study $=$ Insecten als duurzame diervoedergrondstof in varkens- en pluimveevoeders: een haalbaarbeidsstudie. Lelystad, The Netherlands: Wageningen UR Livestock Research.

6. Plantinga EA, Bosch G \& Hendriks WH (2011) Estimation of the dietary nutrient profile of free-roaming feral cats: possible implications for nutrition of domestic cats. Br J Nutr 106, S35-S48.

7. Boisen S \& Fernández JA (1997) Prediction of the total tract digestibility of energy in feedstuffs and pig diets by in vitro analyses. Anim Feed Sci Technol 68, 277-286.

8. Hervera M, Baucells MD, Blanch F, et al. (2007) Prediction of digestible energy content of extruded dog food by in vitro analyses. J Anim Physiol Anim Nutr 91, 205-209.

9. Jha R, Bindelle J, Van Kessel A, et al. (2011) In vitro fibre fermentation of feed ingredients with varying fermentable carbohydrate and protein levels and protein synthesis by colonic bacteria isolated from pigs. Anim Feed Sci Tecbnol 165, 191-200.

10. ISO (2005) Animal Feeding Stuffs - Determination of Content and Calculation of Crude Protein Content - Part 1: Kjeldabl Method ISO
5983-1). Geneva, Switzerland: International Organization for Standardization.

11. ISO (1999) Animal Feeding Stuffs - Determination of Fat Content (ISO 6492). Geneva, Switzerland: International Organization for Standardization.

12. ISO (2005) Animal Feeding Stuffs - Determination of Amino Acids Content (ISO 13903). Geneva, Switzerland: International Organization for Standardization.

13. Kerr KR, Beloshapka AN, Morris CL, et al. (2013) Evaluation of four raw meat diets using domestic cats, captive exotic felids, and cecectomized roosters. J Anim Sci 91, 225-237.

14. NRC (2006) Nutrient Requirements of Dogs and Cats. Washington, DC, USA: National Academies Press.

15. Finke MD (2013) Complete nutrient content of four species of feeder insects. Zoo Biol 32, 27-36.

16. Newton GL, Booram CV, Barker RW, et al. (1977) Dried Hermetia Illucens larvae meal as a supplement for swine. J Anim Sci 44, 395-400.

17. St-Hilaire S, Sheppard C, Tomberlin JK, et al. (2007) Fly prepupae as a feedstuff for rainbow trout, Oncorbynchus mykiss. $J$ World Aquac Soc 38, 59-67.

18. Finke MD (2007) Estimate of chitin in raw whole insects. Zoo Biol 26, $105-115$.

19. Ramos-Elorduy J, González EA, Hernández AR, et al. (2002) Use of Tenebrio molitor (Coleoptera: Tenebrionidae) to recycle organic wastes and as feed for broiler chickens. J Econ Entomol 95, 214-220.

20. Clapper GM, Grieshop CM, Merchen NR, et al. (2001) Ileal and total tract nutrient digestibilities and fecal characteristics of dogs as affected by soybean protein inclusion in dry, extruded diets. J Anim Sci 79, 1523-1532.

21. Johnson ML, Parsons CM, Fahey GC Jr, et al. (1998) Effects of species raw material source, ash content, and processing temperature on amino acid digestibility of animal by-product meals by cecectomized roosters and ileally cannulated dogs. I Anim Sci 76, 1112-1122.

22. Murray SM, Patil AR, Fahey GC Jr, et al. (1997) Raw and rendered animal by-products as ingredients in dog diets. J Anim Sci 75, 2497-2505.

23. Pretorius Q (2011) The evaluation of larvae of Musca domestica (common house fly) as protein source for broiler production. Master of Science, Stellenbosch University, Matieland, South Africa.

24. Rumpold BA \& Schlüter OK (2013) Potential and challenges of insects as an innovative source for food and feed production. Innov Food Sci Emerg Tecbnol 17, 1-11.

25. van der Spiegel M, Noordam MY \& van der Fels-Klerx HJ (2013) Safety of novel protein sources (insects, microalgae, seaweed, duckweed, and rapeseed) and legislative aspects for their application in food and feed production. Compr Rev Food Sci Food Saf 12, 662-678. 